\title{
Sinisimpukkajauhon (Mytilus edulis) aminohappojen sulavuus porsailla
}

\author{
Kirjoittajat: Tiina Kortelainen ${ }^{1)}$, Hilkka Siljander-Rasi ${ }^{2)}$, Mikko Tuori ${ }^{3)}$, Kirsi Partanen ${ }^{4)}$ \\ 1)_Luonnonvarakeskus,Vihreä teknologia, PL 18,01301Vantaa tiina.kortelainen@luke.fi \\ 2) Luonnonvarakeskus, Vihreä teknologia, PL 18,01301 Vantaa hilkka.siljander-rasi@luke.fi \\ 3) Luonnonvarakeskus, Vihreä teknologia, PL 18, 01301 Vantaa \\ 4) Nykyinen osoite: Snellmanin Lihanjalostus Oy, Kuusisaarentie 1, 68600 Pietarsaari
}

\section{TIIVISTELMÄ}

ICOPP -tutkimushankkeessa tehdyn kokeen tavoitteena oli määrittää Ruotsissa luonnonmukaisesti tuotetun, EU:ssa sioille toistaiseksi kielletyn eläinperäisen rehuaineen, sinisimpukkajauhon (Mytilus edulis), ravintoaineiden kokonaissulavuus ja aminohappojen standardoitu ohutsuolisulavuus (SID) porsailla. Jauho oli valmistettu kuorituista sinisimpukoista. Koe-eläiminä oli 24 risteytysporsasta (alkupaino noin $19 \mathrm{~kg}$ ) pariruokinnalla. Koeruokintoja oli aluksi kaksi: 1) vähäproteiininen rehu aminohappojen endogeenisen perustason erityksen määritystä varten, 2) rehu, jossa sinisimpukkajauho oli ainoa valkuaisen lähde, $30 \%$ rehun kuiva-aineessa (KA). Sinisimpukkaryhmän porsaat sairastuivat ripuliin, joten ravintoaineiden kokonaissulavuutta ei voitu määrittää. Sinisimpukkarehua laimennettiin heravalkuaisjauhoa sisältävällä rehulla. Muutosten jälkeen sinisimpukkakäsittelyt olivat: sinisimpukkajauhoa $12 \%$ rehun KA:ssa ja sinisimpukkajauhoa $18 \%$ rehun KA:ssa. Kokeen lopussa siat lopetettiin aminohappojen ohutsuolisulavuuden määrittämistä varten. Sinisimpukkajauho sisälsi $684 \mathrm{~g}$ raakavalkuaista, $105 \mathrm{~g}$ raakarasvaa ja $94 \mathrm{~g}$ tuhkaa/kg KA. Lysiiniä oli 47,8 g, treoniinia 30,6 g, metioniinia 17,0 g, kystiiniä $8,4 \mathrm{~g}$ ja valiinia $29,8 \mathrm{~g} / \mathrm{kg}$ ka. Koerehujen aminohappojen näennäiset ohutsuolisulavuudet (AID) olivat 69,9 - 84,9\% alemmalla sinisimpukkatasolla ja 77,9 - 87,2 \% ylemmällä sinisimpukkatasolla. Sinisimpukkajauhon välttämättömien aminohappojen AID oli 66,3 $88,5 \%$ alemmalla sinisimpukan lisäystasolla ja 71,8 - 87,6 \% ylemmällä sinisimpukkatasolla. Lysiinin ja metioniinin AID oli parempi ylemmällä sinisimpukkatasolla. Aminohappojen endogeeninen perustason eritys oli tavanomaista suurempi tässä kokeessa, joten sinisimpukkajauhon aminohappojen SID:n laskemiseen käytettiin kolmen muun ICOPP-projektin sulavuuskokeen endogeenisen erityksen keskiarvoja. Koska aminohappojen AID:n hajonta oli suurta alemmalla sinisimpukkatasolla, SID-arvot laskettiin käyttämällä ainoastaan suuremman sinisimpukkatason havaintoja. Sinisimpukkajauhon välttämättömien aminohappojen SID -arvot olivat 80,9-92,5\%. Lysiinin SID oli $89,7 \%$, metioniinin $89,1 \%$, kystiinin $71,3 \%$, treoniinin 80,9 \% ja valiinin $89,7 \%$. Tulokset osoittavat sinisimpukkajauhon sisältävän lähes kalajauhon veroisesti aminohappoja, mutta niiden sulavuus ei ole yhtä hyvä kuin kalajauhossa. Tärkeimpien aminohappojen sulavuus on verrattavissa soijarouheeseen. Sinisimpukkajauhon runsas käyttö aiheutti ripulia porsaille ja Ruotsissa samalla erällä tehdyssä kokeessa myös broilereille. Käyttömäärää pienennettäessä ripulia ei ollut. Sinisimpukkajauhon käyttö rehuna edellyttää lainsäädännön muutoksia ja tuotannon taloudellisuus tulisi myös selvittää.

\section{Asiasanat:}

Sika, porsas, sulavuus, ohutsuolisulavuus, aminohapot, sinisimpukka, Mytilus edulis 


\section{Johdanto}

Sinisimpukkajauho voisi olla yksi vaihtoehto uudeksi valkuaislähteeksi sikojen ruokinnassa ja asia on käsittelyssä EU:n rehulainsäädännössä. Aikaisemmat tutkimukset munivilla kanoilla osoittavat sinisimpukkajauhon olevan varteenotettava valkuaislähde, mikäli sinisimpukan tuotanto saadaan taloudellisesti järkeväksi (Jönsson and Elwinger 2009, Jönsson ja Holm 2009). Sinisimpukoiden valkuaisarvosta sioille on vain vähän tietoa ja sitä on tutkittava.

Tämän ICOPP-hankkeen tutkimuksen alkuperäisenä tavoitteena oli määrittää sinisimpukkajauhon ravintoaineiden näennäinen kokonaissulavuus ja aminohappojen standardoitu ohutsuolisulavuus (standardised ileal digestibility, SID) kasvavilla sioilla.

\section{Aineisto ja menetelmät}

\section{Koe-eläimet, koemalli ja koerehut}

Kokeessa oli yhteensä 24 vieroitettua, 40 - 49 pv:n ikäistä risteytysporsasta, joiden alkupaino oli 19 kg. Porsaat olivat pariruokinnalla. Kuivikkeita ei käytetty sonnankeräyksen aikana ja kokeen lopussa, vaan tilalle annettiin puinen virikelelu. Sinisimpukkajauho tuotiin Ruotsista SLU:lta (Swedish University of Agricultural Sciences), tutkittiin salmonellan varalta ja jauhettiin hienoksi. Koeryhmiä oli aluksi kaksi: 1) vähäproteiininen rehu aminohappojen endogeenisen perustason erityksen määritystä varten, 2) sinisimpukkarehurehu, jossa sinisimpukkajauho oli ainoa valkuaisen lähde, $30 \%$ rehun kuiva-aineessa (KA). Sinisimpukkaryhmän porsaat sairastuivat ripuliin, joten ravintoaineiden kokonaissulavuutta ei voitu määrittää. Sinisimpukkarehua laimennettiin heravalkuaistiivistettä (whey protein concentrate, WPC) sisältävällä rehulla. Muutosten jälkeen sinisimpukkakäsittelyt olivat: sinisimpukkajauhoa $12 \%$ rehun KA:sta ja sinisimpukkajauhoa $18 \%$ rehun KA:sta. Koerehujen merkittävimmät raaka-aineet on esitetty taulukosssa 1 . Lisäksi rehuissa oli myös rypsiöljyä, kivennäisiä ja vitamiineja. Koerehujen analysoitu kemiallinen koostumus on esitetty taulukossa 2. Sikoja ruokittiin kolmesti päivässä, aluksi $100 \mathrm{~g} \mathrm{KA} /$ metabolinen elopainokilo ja varsinaisella koejaksolla $200 \mathrm{~g} \mathrm{KA} /$ metabolinen elopainokilo. Rehunvaihdot porrastettiin. Viimeinen eli varsinainen koejakso kesti 8 päivää ja tätä ennen oli kaksi totutusjaksoa (yhteensä 14 pv), jonka aikana porsaat totuttelivat vieroituksen jälkeen kuivaan rehuun, uuteen ympäristöön ja karsinatovereihin.

Kokeen lopussa (koepäivä 21 tai 26, sinisimpukkaryhmien siat myöhemmin, koska suunnitelma muuttui ripulin takia) siat ruokittiin porrastetusti ja lopetettiin 3,5 tunnin kuluttua viimeisestä ruokinnasta. Vatsaontelo avattiin ja ruokasulaa kerättiin ohutsuolesta (n. 50-60cm matkalta ohutsuolen ja umpisuolen liitoksesta taaksepäin) aminohappojen ohutsuolisulavuuden määrittämistä varten. Titaniumdioksidia käytettiin rehussa merkkiaineena ( $3 \mathrm{~g} / \mathrm{kg} \mathrm{KA})$. Ruokasulanäytteet pakastettiin ja niistä analysoitiin kuiva-aine, tuhka, aminohapot ja merkkiaine.

Taulukko 1. Koerehujen raaka-aineet.

\begin{tabular}{l|ccc}
\hline & \multicolumn{3}{|c}{$\underline{\text { Jakso 2 }}$} \\
& $\begin{array}{c}\text { Vähä- } \\
\text { proteiininen } \\
\text { rehu 634 }\end{array}$ & $\begin{array}{c}\text { Sini- } \\
\text { sipukka- } \\
\text { rehu 635 }\end{array}$ & $\begin{array}{c}\text { WPC }^{1} \\
\text { rehu } \\
\text { Raaka-aineet, g/kg: }\end{array}$ \\
\hline Sinisimpukkajauho & \multicolumn{4}{|c}{300} \\
Ohratärkkelys & 767.4 & 562.5 & 687.4 \\
WPC75 & 50 & & 210 \\
Sokeri & 80 & 80 & \\
Selluloosa & 30 & 30 & 30 \\
\hline
\end{tabular}

$\mathrm{WPC}^{1}=$ heravalkuaistiiviste 
Taulukko 2. Koerehujen analysoitu kemiallinen koostumus, g/kg KA.

\begin{tabular}{lccc}
\hline & $\begin{array}{c}\text { Vähäproteiininen } \\
\text { rehu 634 }\end{array}$ & $\begin{array}{c}\text { Sinisimpukka- } \\
\text { rehu } \\
635^{*}\end{array}$ & $\begin{array}{c}\text { WPC- } \\
\text { rehu } \\
640^{*}\end{array}$ \\
\hline Kuiva-aine, g/kg & 923 & 924 & 926 \\
Tuhka & 40 & 56 & 39 \\
Raakavalkuainen & 30 & 217 & 109 \\
Aminohapot, g/kg KA & & & \\
Lysiini & 2,7 & 15,3 & 10,5 \\
Metioniini, & 1,0 & 5,7 & 3,2 \\
Kystiini & 0,6 & 2,3 & 2,4 \\
Treoniini & 2,1 & 9,7 & 8,0 \\
Valiini & 1,8 & 9,5 & 14,4 \\
\hline
\end{tabular}

\footnotetext{
${ }^{*}$ Ryhmä 2: 400 g/kg KA sinisimpukkarehua $635+600$ g/kg KA WPC-rehua

Ryhmä 3: 600 g/kg KA sinisimpukkarehua $635+400$ g/kg KA WPC-rehua Sinisimpukkarehu 635 sisälsi $30 \%$ sinisimpukkajauhoa.
}

\section{Sulavuuslaskut ja analyysit}

Dieettien aminohappojen näennäinen ohutsuolisulavuus (AID) laskettiin merkkiaineen avulla ja sinisimpukkajauhon aminohappojen AID laskettiin erotusmenetelmällä. Tässä kokeessa perusrehun aminohappojen näennäisinä sulavuusarvoina käytettiin heravalkuaistiivisteen (alhainen laktoosipitoisuus, tuhkaa > $210 \mathrm{~g} / \mathrm{kg}$, nro 8009.626/2/0) taulukkoarvoja Hollannista (CVB 2011). Perustason aminohappojen endogeeninen eritys (g/ kg KA) laskettiin Steinin ym. (2007) mukaan ohutsuolen ruokasulan näytteistä niiltä porsailta, jotka söivät vähäproteiinista rehua. Aminohappojen standardoitu ohutsuolisulavuus laskettiin Steinin ym. (2007) mukaan.

Data analysoitiin käyttämällä SAS MIXED proseduuria ja mallia, jossa oli kiinteinä vaikutuksina sukupuoli ja koekäsittely ja näiden yhdysvaikutus. SID arvot laskettiin SAS GLM proseduurilla, jossa mallissa oli sukupuolen vaikutus . Leikkojen ja imisien yleiskeskiarvoa (general mean) käytettiin sinisimpukkajauhon SID arvona ja keskiarvon keskivirhe laskettiin jakamalla keskineliövirhe (root MSE) havintojen kokonaismäärän neliöllä.

\section{Tulokset}

Sinisimpukkajauhon analysoitu kemiallinen koostumus on esitetty taulukossa 3. Raakavalkuaista oli lähes $70 \%$ ja raakarasvaa n. $10 \%$. Tässä tutkimuksessa sinisimpukkajauho sisälsi myös pieniä määriä NDF:ää $(5,9 \%)$ ja ADF:ää $(1,7 \%)$, mutta muissa tutkimuksissa kuitumäärityksiä on tehty vain harvoin. ADF-typen osuus, joka ilmaisee eläimelle käyttökelvottoman typen osuutta, oli tässä tutkimuksessa mitätön. Sinisimpukan hiilihydraatit ovat pääosin glykogeenia, jota simpukka hyödyntää silloin, kun ravinnon saatavuus on alhainen.

Aminohappojen endogeeninen perustason eritys oli tavanomaista suurempi tässä kokeessa, joten sinisimpukkajauhon aminohappojen SID:n laskemiseen käytettiin kolmen muun ICOPP-projektin sulavuuskokeen endogeenisen erityksen keskiarvoja. Koska aminohappojen AID:n hajonta oli suurta alemmalla sinisimpukkatasolla, SID arvot laskettiin käyttämällä ainoastaan suuremman sinisimpukkatason havaintoja. Sinisimpukkajauhon välttämättömien aminohappojen SID arvot olivat $80,9-92,5 \%$ (taulukko 4). 
Taulukko 3. Sinisimpukkajauhon analysoitu kemiallinen koostumus, g/kg KA.

\begin{tabular}{lc}
\hline & $\begin{array}{c}\text { Sinisimpukka- } \\
\text { jauho }\end{array}$ \\
\hline Kuiva-aine, g/kg & 956 \\
Tuhka & 94 \\
Raakavalkuainen & 684 \\
Raakarasva & 105 \\
Aminohapot, g/kg KA & \\
Välttämättömät & \\
Arginiini & 45,0 \\
Histidiini & 11,9 \\
Isoleusiini & 27,0 \\
Leusiini & 43,1 \\
Lysiini & 47,8 \\
Metioniini & 17,0 \\
Fenyylialaniini & 23,3 \\
Treoniini & 30,6 \\
Valiini & 29,8 \\
Ei-välttämättömät & \\
Alaniini & 31,7 \\
Asparagiinihappo & 65,1 \\
Kystiini & 8,4 \\
Glutamiinihappo & 81,0 \\
Glysiini & 39,4 \\
Proliini & 25,7 \\
Seriini & 31,3 \\
Tyrosiini & 23,6 \\
\hline &
\end{tabular}


Taulukko 4. Sinisimpukkajauhon SID arvot.

\begin{tabular}{lccc}
\hline Aminohappo & Sinisimpukkajauho & n. & SEM \\
\hline Välttämättömät & 92,5 & 8 & 1,80 \\
Arginiini & 87,7 & 8 & 2,23 \\
Histidinii & 86,2 & 8 & 2,74 \\
Isoleusiini & 86,5 & 8 & 2,49 \\
Leusiini & 89,7 & 8 & 1,56 \\
Lysiini & 89,1 & 8 & 1,99 \\
Metioniini & 84,1 & 8 & 2,94 \\
Fenyylialaniini & 80,9 & 8 & 2,36 \\
Treoniini & 89,7 & 8 & 2,77 \\
Valiini & & & \\
Ei-välttämättömät & 84,1 & 8 & 2,18 \\
Alaniini & 84,1 & 8 & 2,31 \\
Asparagiinihappo & 71,3 & 8 & 4,47 \\
Kystiini & 84,2 & 8 & 3,14 \\
Glutamiinihappo & 87,8 & 8 & 2,50 \\
Glysiini & 95,8 & 5 & 2,06 \\
Proliini & 85,1 & 8 & 2,08 \\
Seriini & 81,1 & 8 & 3,72 \\
Tyrosiini & & & \\
\hline n = havaintojen lkm & & &
\end{tabular}

\section{Tulosten tarkastelu}

Tämän kokeen sinisimpukkajauhon raakavalkuais-, raakarasva- ja tuhkapitoisuus oli verrattavissa Jönsonin ja Elwingerin (2009) sekä Bergen ja Austrengin (1989) tuloksiin. Nørgaard'in ym. (2015) kokeessa sinisimpukkajauho sisälsi hieman vähemmän raakavalkuaista (605 ja $684 \mathrm{~g} / \mathrm{kg} \mathrm{KA}$ ) ja tuhkaa (81 ja 94 g/kg KA), mutta enemmän raakarasvaa (161 ja 105 g/kg KA) kuin tässä kokeessa. Okumus ja Striling (1998) tutkivat sinisimpukan koostumuksen kausiluontoista vaihtelua ja selvittivät, että sinisimpukan lihan orgaaninen aine sisälsi raakavalkuaista $518-824 \mathrm{~g} / \mathrm{kg} \mathrm{KA}$, raakarasvaa $26-127$ g/kg KA ja raakahiilihydraatteja $86-358$ g/kg KA. Tuhkan määrä oli $42-142$ g/kg KA. Tämän tutkimuksen sinisimpukkajauhon raakavalkuais- ja raakarasvapitoisuus on verrattavissa kalajauhon taulukkoarvoihin. Sinisimpukan lysiinin, metioniini ja treoniinin pitoisuudet olivat verrattavissa kalajauhon taulukkoarvoihin. Kystiiniä oli sinisimpukassa hiukan enemmän ja valiinia hiukan vähemmän kuin kalajauhossa (CVB 2011, EvaPig 2008).Tutkimuksessa määritetty sinisimpukan aminohappokoostumus on verrattavissa aikaisempiin tutkimuksiin. Jönsson ja Elwinger (2009) raportoivat hiukan korkeampia aminohappojen määriä ja Berge ja Austreng (1989) hiukan alhaisempia arvoja joillekin aminohapoille verrattuna tähän tutkimukseen. Nørgaard'in ym. (2015) kokeessa välttämättömien aminohappojen pitoisuudet olivat yleisesti ottaen hiukan korkeampia kuin tässä kokeessa.

Alkuperäinen tavoite oli syöttää sinisimpukkajauhoa ainoana valkuaisen lähteenä rehussa $(300 \mathrm{~g} / \mathrm{kg}$ KA). Porsaille tuli kuitenkin ripuli kun sinisimpukkajauhoa alettiin syöttää. Porsaat kokivat hyvin lyhyen ajan sisällä myös muita ripulille altistavia tekijöitä, kuten vieroituksen, uudet karsinatoverit sekä rehun ympäristön ja lämpötilan vaihdon. Sinisimpukkajauholla saattoi kuitenkin olla ripulia aiheuttava vaikutus, sillä porsaat, jotka söivät vähäproteiinista rehua, eivät sairastuneet ripuliin. Koeryhmien korjausten jälkeen alhaisempi sinisimpukkajauhon taso oli melko alhainen (12 \% KA:sta), mikä saattoi johtaa suureen vaihteluun aminohappojen näennäisessä sulavuudessa. Tämän suuren vaihtelun vuoksi standardoidut aminohappojen ohutsuolisulavuudet laskettiin käyttämällä vain korkeamman lisäystason (18\% KA:sta) havaintoja. 
Aminohappojen perustason endogeenisen erityksen mittaus tarvitaan, jotta voidaan laskea standardoidut aminohappojen ohutsuolisulavuudet näennäisistä sulavuuksista. Tässä tutkimuksessa porsaiden aminohappojen perustason endogeeninen eritys oli suurta verrattuna aikaisempiin tutkimuksiin, jotka on tehty vanhemmilla sioilla ja dieeteillä, joissa on hyvin sulavia aminohappoja (Jansman ym. 2002). Siksi sinisimpukkajauhon SID laskuissa käytettiin kolmen muun ICOPP tutkimuksen aminohappojen perustason endogeenisten arvojen keskiarvoja. Nuorten sikojen $(<30 \mathrm{~kg}$ elopaino) aminohappojen perustason endogeenisen erityksen tasosta on vain vähän tietoa. Ruokintatasolla ja totuttelujakson pituudella voi myös olla vaikutusta aminohappojen endogeenisen eritykseen.

Sinisimpukkajauhon aminohappojen AID ja SID arvot olivat melko korkeita (AID 66,3 - 88,5\% ja SID 80,9 \% - 92,5 \%), Kystiinin SID oli alhaisin (71,3 \%). Tämän kokeen sinisimpukkajauhon aminohappojen SID arvot olivat yleisesti ottaen hiukan korkeampia kuin Nørgaard'in ym. (2015) kokeessa. Kaikkien välttämättömien aminohappojen sulavuudet olivat yhtä suuria tai korkeampia kuin Nørgaard'in ym. (2015) kokeessa ja valiinin SID arvo oli reilusti korkeampi (90 ja 82 \%).

\section{Johtopäätökset}

Tulokset osoittavat, että sinisimpukkajauho tarjoaa hyvin sulavia aminohappoja, jotka voivat tasapainottaa aminohappokoostumusta sikojen ruokinnassa. Ruokintakokeiden avulla on selvitettävä paremmin sinisimpukkajauhon käytön vaikutuksia porsaiden terveyteen. Sinisimpukkajauholla voitaisiin monipuolistaa luomusikojen valkuaislähteitä, mutta sinisimpukkajauhon tuotannon taloudellisia aspekteja pitää tutkia. Porsaiden aminohappojen perustason endogeeninen eritys tarvitsee myös lisää tutkimusta.

\section{Kirjallisuus}

Berge, G.M. \& Austreng, E. 1989. Blue Mussel in Feed for Rainbow Trout. Aquaculture 81:79-90.CVB 2011. CVB 2011. Chemical compositions and nutritional values of feed materials. Centraal Veevoederbureau: Lelystad, The Netherlands.

EvaPig 2008. EvaPig® Evaluation of Pig feeds. Energy, amino acids and phosphorus values for pigs. INRA, AFZ, Ajinomoto Eurolysine S.A.S. Viitattu 20.11.2014 osoitteessa www.evapig.com

Fan, M.Z. \& Sauer, W.C. 1995. Determination of Apparent ileal amino acid digestibility in peas for pigs with the direct, difference and regression method. Livestock Production Science 44:61-72.

Jansman, AJM., Smink, W., van Leeuwen, P. \& Rademacher, M. 2002. Evaluation through literature data of the amount and amino acid composition of basal endogenous crude protein at the terminal ileum of pigs. Animal Feed Science and Technology 98:49-60.

Jönsson, L. \& Elwinger, K. 2009. Mussel meal as a replacement for fish meal in feeds for organic poultry - a pilot short-term study. Acta Agriculturae Scandinavica Section A, 59:22-27.

Jönsson, L. \& Holm, L. 2009. Effects of toxic and non-toxic blue mussel meal on health and product quality of laying hens. Journal of Animal Physiology and Animal Nutrition 94:405-412.

Okumuş, İ. \& Stirling, H.P. 1998. Seasonal variations in the meat weight, condition index and biochemical composition of mussels (Mytilus edulis L.) in suspended culture in two Scottish sea lochs. Aquaculture 159:249-261.

Nørgaard, J.V., Petersen, J.K. Tørring, D.B., Jørgsen, H. \& Lærke, H.N. 2015. Chemical composition and standardized ileal digestibility of protein and amino acids from mussel, starfish, and fish silage in pigs. Animal Feed Science and Technology 205: 90-97.

Stein, HH., Sève, B., Fuller, MF., Moughan, PJ. \& de Lange, CFM. 2007. Invited review: Amino acid bioavailability and digestibility in pig feed ingredients: Termonology and application. Journal of Animal Science 85:172-180. 